\title{
Conference Group for Central European History
}

\section{Newsletter}

\section{Spring 2000}

Dear Colleagues,

Here is the Spring 2000 Newsletter. Items of particular interest include the report of the Editor of $\mathrm{CEH}$, the report of the 1999-2000 Article Prize Committee, the announcement of the competition for the book prize to be awarded in January 2001, and the announcement that the Editorship of Central European History will become available in the spring/summer of 2004.

Kees Gispen

* * * *

Business Meeting, Washington, DC

8 January 2000

\section{Introductory remarks and welcome}

President Ronnie Hsia chaired the meeting. Hsia welcomed all those in attendance and expressed his pleasure at the prospect of turning over his responsibilities to the new president, Mary Jo Maynes, at the end of the business meeting. Maynes will serve until January 2001. Hsia invited everyone to participate in the Bierabend (which commenced at 6:00 P.M. in an adjacent room and was heavily attended). The minutes of last year's business meeting were approved.

\section{Report of the Executive Secretary and Treasurer}

Kees Gispen reported on the Conference Group's finances. He presented the following overview. 
Budget summary January 1999-January 2000

Balance Forward

8 January 1999

$5,107.05$

Income

AHA interest+

446.00

Humanities Press royalties* 5,000.00

Total Income

Expenses

1999 NCC dues

$5,446.00$

1999 Book Prize (Canning) 750.00

1999 Subsidy to CEH $\quad 2,500.00$

1998 Subsidy Transatl.

Seminar $\quad 1,000.00$

1999 Subsidy Transatl.

Seminar $\quad 1,000.00$

CG advertisement in AHA

program $\quad 75.00$

Reimbursement of Executive

Secretary expenses

Total expenditures

134.24

Net income

$5,959.24$

$<513.24>$

Balance Forward

January 7, 2000

4,593.81

Explanations: + The CGCEH maintains an interest-bearing investment/savings account with the AHA. The balance of this account, as of October 1999, was 9,706 percent.

* HPI/Brill Royalties. When HPI was taken over by Brill in 1998, an interruption and change in royalty payments occurred. Because of Brill's royalty accounting, which takes place in the spring following the year for which royalties are due, the exact amount of royalties owed in a given year becomes known only the following year. For that reason, Brill pays the CGCEH an advance during the year when royalties are earned, and a final payment when it settles its accounts the following spring. In 1998 , the CG received $\$ 3,500$. In 1999 , we received, in May, $\$ 1,000$ for the balance owed to us from 1998; in addition, in November we received $\$ 4,000$, as an advance for royalties earned in 1999 .

Budget Proposal January 2000-January 2001

Balance Forward

7 January 2000

Projected Income AHA interest $4,593.81$

Brill royalties

440.00

Total projected income

$5,000.00$

$5,440.00$ 
Projected

Expenses
Article prize award,

January 2000

2000 Bierabend (estimate)

2000 NCC dues

2000 Subsidy to $\mathrm{CEH}$

2000 Subsidy Transatl.

Seminar

2000 Savings at AHA

Total projected expenditures

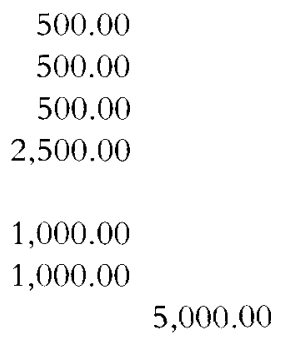

Projected net

income

Projected balance

Forward

January 2001

The business meeting voted to approve the executive secretary's report for 1999 and the budget proposal for 2000 .

\section{Report of the Editor of Central European History}

Ken Barkin presented the following statistical overview

Publishing record for 1999 :

Number of issues 4 (Vol. 32, nos. 1-4)

Number of articles 12

Number of review articles

Number of book reviews 70

Other items 2 (Mosse obituary, Newsletter)

At the publisher:

Vol. 33: 1
Review Articles

1
Book Reviews 18
Other 2 (Obituary, Newsletter)

Current editorial status (January 2000):

In process

Articles accepted

Review articles accepted

Articles to be revised

Articles at referees
Vol. 33:2 (2 articles, 2 review articles, 15 book reviews) 
Articles pending

1

Articles rejected in 1998

Book reviews on hand

160

Book reviews outstanding 998

Barkin thanked David Sabean, Peter Hayes, and Barbara Miller Lane, who have left the board of Central European History after serving a five-year term. The new board members beginning a five-year term are: Helmut Walser Smith, Jerffrey Herf, Ronnie Po-chia Hsia, and Omer Bartov. Barkin announced that henceforth there will be a maximum length of 65 pages for articles and 45 pages for review articles. The working relationship between the editorial office and the new publisher, Brill Academic Publishers of Leiden and Boston, is excellent.

Finally, Barkin commemorated the passing away in 1999 of Jonathan Knudsen, a long-time member and wonderful friend. (Please see Knudsen's obituary in $C E H$, vol. 33:1.)

Following the report, President Hsia was very pleased to announce that Kenneth Barkin, whose term as editor expires next year, has agreed to the executive committee's request to accept another, partial term as editor of Central European History, through the spring of 2004. On behalf of the other members of the Executive Committee and the Conference Group's membership as a whole, Hsia expressed his thanks to Ken Barkin and assistant editor Ursula Marcum for the superb work they have done editing the journal during the past ten years. The backlog that existed in the early 1990s has been entirely removed. Under Barkin's leadership the journal has become ever more successful and acquired a reputation for excellence that is amply deserved. Barkin also presided over the successful transfer of $C E H$ from Humanities Press International to Brill Academic Publishers, which now owns Humanities Press.

\section{Report of the 1999-2000 Article Prize Committee}

The next item of business was the report of the article prize committee, which consisted of Thomas Brady, Pieter Judson, and Doris Bergen (chair). The committee considered articles published in 1997 and 1998. This year's winner was Karl F. Bahm, for his article, "Beyond the Bourgeoisie: Rethinking Nation, Culture, and Modernity in Nineteenth-Century Central Europe," published in the Austrian History Yearbook, vol. 29 (1998): pt. 1, 19-35. Doris Bergen read the following statement:

The article prize committee of the Conference Group for Central European History is pleased to announce the winner for 1998: Karl F. Bahm, for 
"Beyond the Bourgeoisie: Rethinking Nation, Culture, and Modernity in Nineteenth-Century Central Europe," published in the Austrian History Yearbook, vol. 29 (1998): part 1, 19-35. Karl F. Bahm is Assistant Professor of History at the University of Southern Mississippi, Hattiesburg. Professor Bahm's title reveals the ambitious scope of this impressive article. In fifteen concise, tightly argued pages, he looks "beyond the bourgeoisie" to consider the lower classes and their role in constructing national identities, specifically in northwestern Bohemia in the late nineteenth century. By shifting the perspective from elites to workers and from macro to micro, Bahm does open up new ways to think about "nation, culture, and modernity in nineteenthcentury Central Europe." Nationalisms, he suggests, are complex and have multiple sources. But even the most cunning national elites cannot invent the nation out of nothing; "real cultural and social factors of identity" like language and ethnicity provide the "preexisting building blocks" necessary for national mobilization. Viewed in this way, nationalism is not just a trick played by manipulative members of the bourgeoisie intent on supporting their own interests; it is also an expression of "active and autonomous" lowerclass engagement. At the turn of our own century, in a time when we alternate between celebrating the end of the nation and decrying the deadly persistence of aggressive nationalisms, Bahm's findings are both timely and unsettling. Bahm illustrates his points with a case study of a workingclass father and son in Bohemia from the 1860s to World War I. He supplements the written recollections of Wenzel and Heinrich Holek with a range of sources in Czech and German. Indeed, Bahm's footnotes themselves are a vivid reminder of what might seem to be a paradox in the study of Central Europe: one cannot understand the nationalisms of the region without considering their transnational and international contexts. At the same time, Bahm's article demonstrates the potential of microhistory and Alltagsgeschichte as vivid, compelling ways to illuminate broad social and political processes. Sensitivity to nuance and attention to detail on a small scale, Bahm shows, pay off with insights into the big picture, too. Everyone interested in the dynamics of nationalism, whether at the level of class, state, family, or individual, can learn something from Karl Bahm's significant contribution to the study of a phenomenon so central to the history of the last two centuries.

After reading the statement, Bergen invited Bahm to come to the front, where he accepted the prize amid warm applause from those in attendance.

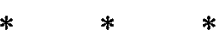

\section{Report of the Nominating Committee}

Next on the agenda was the report of the 1999 nominating committee, which consisted of Geoff Eley, Tony LaVopa, and Istvan Deak. President Hsia announced the committee's nominations, which were approved by voice vote. 


\section{CONFERENCE GROUP FOR CENTRAL EUROPEAN HISTORY}

Vice-President Elect: David Crew, University of Texas at Austin

Executive Committee (a three-year term): Doris Bergen, University of Notre Dame

The term of service for the above positions commenced on 9 January 2000.

\section{Report of the Archives Committee}

Owing to Alan Steinweis's resignation from his position as chair of the committee, there was no report from the Archives Committee.

The archives committee consists of:

David Barclay, Kalamazoo College

John Connelly, University of California, Berkeley

Carole Fink, Ohio State University

Geoffrey Giles, University of Florida (ex officio)

Gerhard Weinberg, University of North Carolina at Chapel Hill

The executive committee is hoping to find a new chair of the committee soon.

\section{Report from the German Historical Institute in Washington}

Ronnie Hsia welcomed Christoph Mauch, Interim Director of the German Historical Institute in Washington. Mauch spoke briefly about the work of the GHI. He expressed his gratitude for the Conference Group's financial support and cosponsorship of the Transatlantic Seminar and made a plea for continued support in the future. The Executive Committee has recommended continuing the annual subsidy to the Transatlantic Seminar, albeit at a reduced rate beginning in 2001. Mauch expressed his gratitude for this expression of support. Mauch also mentioned that the search for a new permanent director of the $\mathrm{GHI}$ is continuing.

\section{Report from the Society for Austrian and Habsburg History}

There was no report from the Society for Austrian and Habsburg History. It was reported that the new secretary of the organization is Gary Cohen, University of Oklahoma. 
$* \quad * \quad *$

\section{New Business}

\section{Book Prize Name}

The only item of new business was discussion of naming the book prize. Konrad Jarausch spoke briefly about the benefits of naming the Conference Group's bookprize. A named prize will address the problem of anonymity, give the prize greater visibility and raise its overall standing in the profession. The business meeting approved the executive board's recommendation to generate proposals for a book prize name, to be voted on at the next business meeting.

The business meeting adjourned at 5:55 P.M. Incoming president M.J. Maynes began her official duties by inviting the audience to the Bierabend next door.

* $\quad * \quad *$

\section{Announcements}

\section{Book Prize Competition}

In January 2001 the Conference Group will award its biennial prize of $\$ 750$ for the best book in Central European history published during 1998 and 1999. Central European history is understood to include all German-speaking countries as well as areas previously included within the Habsburg monarchy. This year the prize competition is open to books published in 1998 or 1999, in English, by permanent residents of North America. The Conference Group discourages submissions of reprints, second editions, multi-authored anthologies, and document publications. Letters of nomination for the prize may be submitted by authors, publishers, or others and should be addressed to the chair of the book prize committee, Professor Helmut. W. Smith, Department of History, P.O. Box 1802, Sta. B., Vanderbilt University, Nashville, TN 37235, email: helmut.w.smith@vanderbilt.edu. Professor Smith requests that books be sent to his home address: 2006 19th Ave. South, Nashville, TN 37212. Nomination deadline: 30 June 2000 .

Three copies of each book nominated should be submitted: one to the committee chair, and one each to the other two members of the prize committee, Professor Eric Weitz, Department of History, University of Minnesota, 267 19th Avenue South, Minneapolis, MN 55455-0406, email: weitz004@tc.umn.edu and Professor James V. H. Melton, Department of History, Emory University, Atlanta, GA 30322, email: jmelt01@emory.edu. Books should be postmarked no later than 30 June 2000 . 
For further information, please contact the executive secretary of the Conference Group, Prof. Kees Gispen, Department of History, University of Mississippi, University, MS 38677, email: hsgispen@olemiss.edu, telephone: 661-915-7148, fax: 662-915-7033.

\section{Editorship of Central European History}

The editorship of Central European History will become vacant in the spring of 2004, when Ken Barkin, the current editor, will retire. Individuals interested in the position of editor of Central European History after it becomes vacant are encouraged to contact any member of the executive committee or the executive secretary and treasurer.

\section{Executive Committee}

The members of the Conference Group's 2000 executive committee are:

President: Mary Jo Maynes, University of Minnesota

Vice-President: Konrad Jarausch, University of North Carolina and University of Potsdam

Vice-President Elect: David Crew, University of Texas at Austin

Immediate Past President: Ronnie Po-chia Hsia, New York University

At-Large Member (exp. January 2001): Mary Lindemann, Carnegie-Mellon University

At-Large Member (exp. January 2002): Pieter Judson, Swarthmore College At-Large Member (exp. January 2003): Doris Bergen, University of Notre Dame

Editor of Central European History, Kenneth Barkin, University of California, Riverside

Executive Secretary and Treasurer, Kees Gispen, University of Mississippi

\section{Nominations Committee}

The Conference Group's 2000 nominating committee is made up of the executive committee. The Committee has nominated David Blackbourn, Harvard University, for the position of Vice-President Elect and Peter Black, United States Holocaust Memorial Museum, for a three-year term on the executive 
committee. Nominations will be voted on at the January 2001 business meeting. Roger Chickering has agreed to serve as the Conference Group's delegate to Friends of the German Historical Institute in Washington. His responsibilities commenced immediately.

\section{Subscriptions to Central European History}

Institutions or members of the Conference Group who are subscribers to CEH but have not been billed or received their subscriptions are urged to contact the publisher immediately. The publisher's address is:

Humanities Press

c/o Brill Academic Publishers

112 Water Street, Suite 400

Boston MA 02109 USA

Tel. 1-800-962-4406 or 1-877-999-7575 (toll free)

Fax 617-263-2324

Email: cs@brillusa.com

Subscribers outside North America, please contact:

Brill Academic Publishers

P.O. Box 9000

2300 PA Leiden

The Netherlands

Phone: +31-71-535-3566

Fax: +31-71-531-7532

E-mail:cs@brill.nl

Brill is located on the web at: http://www.brill.nl/

Readers who would like to post information of interest to other members of the Conference Group should contact the executive secretary:

Kees Gispen

Department of History

University of Mississippi

University, MS 38677

Telephone: 601-232-7148

FAX: 601-232-7033

Email: hsgispen@olemiss.edu 